\title{
Täydellistyykö kaupunki kehittyessään?
}

\section{Harry Schulman}

Kopomaa, Timo (2019). Täydellistyvä kaupunki, kiehtova urbaani. Puheenvuoro kaupunkitilan, kaupunkisuunnittelun ja nykykaupunkilaisuuden muutoksista. 160 s. ISBN 978-952-94-1799-5 (PDF)

Timo Kopomaa on kirjoittanut kirjan hyvän kaupunkielämän ja -ympäristön tavoittelusta tiivistyvässä ja täydentyvässä kaupungissa. Tuloksena on 160 sivua elävästi kirjoitettua tekstiä. Hän on kehitellyt neljä kaupunkikehittämisen mallia ja testaa näiden kykyä erotella kaupunkia täydentäviä rakenteita ja toiminnallisuutta. Tämä kirjaa jäsentävä, punaisena lankana toimiva kehys tarjoaa myös neljä vaihtoehtoista tulevaisuuden visiota kaupunkisuunnittelulle.

Kopomaa havainnollistaa mallinnustaan tapauskohtaisilla kuvauksilla, jotka ovat tutkijataustaisen kirjoittajansa omakohtaisesta kiinnostuksesta nousseita maamerkkejä hänen suunnistuksessaan "kiehtovassa urbaanissa". Kirjassa esitellyt aiheet ja konkreettiset esimerkit koskevat lähinnä Helsinkiä. Niiden rinnalla tarjoillaan myös menetelmäopastusta laadulliseen tutkimukseen.

Kirjan teemat on jaettu lukijalle ohjeita sisältävän johdannon lisäksi kuuteen alalukuun. Neljässä ensimmäisessä Kopomaa esittelee kehittelemänsä mallin peruselementtejä, täydentyvää, mukautuvaa, sulautuvaa ja eriytyvää kaupunkia. Kahdessa viimeisessä luvussa kootaan yhteen kirjassa esiteltyjä täydentyvän kaupungin tarkasteluja ja tiivistyvän kaupungistumisprosessin piirteitä.

Tarkasteluihinsa Kopomaa on hakenut inspiraatiota mm. kaupunkikulttuuria kuvaavista esseistisistä kirjoituksista sekä kolumnistien ja vaihtoehtoista kaupunkia hakevien ryhmittymien teksteistä. Mittakaava, jossa liikutaan, vaihtelee pihoista kaupunginosiin. Välillä vilahtaa myös näkemys yleisemmästä kaupunkikehityksestä historiallisena prosessina. Lajityypiltään kirja vaikuttaakin tutkimuksen ja pamfletin välimuodolta.

Esittelen muutamia poimintoja kirjasta. Täydentyvä kaupunki on kirjan keskeinen teema. Kopomaa tarkastelee monipuolisesti toteutetun tai toteutettavan rakenteen, tapahtuman tai käytännön havaittua tai koettua asemaa, erityisesti paikallisen yhteisön näkökulmasta. Hän näkee täydennysrakentamiselle kaksi toteutustapaa. Aiempaan rakenteeseen sopiva puuttuva pala kaupunkia voidaan ensinnäkin korvata tai olevaa rakennetta voidaan päivittää jatkamalla, 
korottamalla, yhdistämällä ja muokkaamalla. Näille vaihtoehtona on tuottaa uutta luovia rakenneratkaisuja, jotka hyödyntävät olemassa olevaa tilallista avoimuutta. Hän luettelee paljon syitä tai perusteluja täydennysrakentamiselle. Käyttämättömäksi tai vajaakäyttöiseksi mielletty tila halutaan hyödyntää paremmin. Tarvitaan lisää tilaa ja se voi edellyttää myös vanhaa poistavaa uusimista. Voidaan tavoitella taloudellista lisäarvoa. Täydennysrakentamiseen voi liittyä kaupunkikuvallisia tavoitteita.

Täydentyvän urbaanin ympäristösidokseen ja alueidentiteettiin liittyvä paikkasuhde on oleellinen Kopomaan tarkasteluissa. Hän pitää oleellisena sitä, millaisena kaupunkia täydentävän toteutuksen rooli näyttäytyy suhteessa aikaan, ihmisten väliseen vuorovaikutukseen ja kohtaamisiin sekä olemassa olevaan yhdyskuntarakenteeseen. Konkreettinen paikkasuhde on ainutkertainen ja tässä suhteessa erityisen merkityksellinen paikallisen yhteisön näkökulmasta.

Kaupunkikehittämisen mallinsa neljään fyysisrakenteelliseen ja sosiaalistoiminnalliseen perustyyppiin Kopomaa on ottanut vaikutteita psykologi John W. Berryn (1997) kulttuurien kohtaamista jäsentävästä kategorisoinnista: integraatio, assimilaatio, separaatio, marginalisaatio. Berryn leipälaji on kvantitatiivinen survey-tutkimus maahanmuuttajien asenteista ns. akkulturaatiostressissä. Keskeistä Berryn mallissa on yksilöiden ja ryhmien omaksuma suhde toisaalta kulttuuristen erityispiirteiden säilyttämiseen, toisaalta toiseuden tai vieraan kulttuurin kohtaamiseen ja siihen osallistumiseen. Vuorovaikutusta tarkastellaan siis valtakulttuurin ja vähemmistökulttuurin välillä. Integraatiossa säilytetään omaa kulttuuria, mutta ollaan vuorovaikutuksessa. Assimilaatio viittaa sulautumiseen valtakulttuuriin. Separaatio linkittyy haluun erottua ja välttää sekoittumista. Marginalisaatiossa ei tapahdu hakeutumista minkään kulttuurin piiriin ja valtakulttuurin asenne on torjuva. Berryn akkulturaatiomallin soveltuvuus "täydentyvään urbaaniin" olisi ansainnut enemmän pohdintaa. Hyvinvointikäsitteet ja käsitykset ympäristön laadusta ovat kulttuurisidonnaisia, varsinkin kulttuurienvälisissä tilanteissa suurkaupungeissa.

Toinen poimimani esimerkki on "yhdessä parempi kaupunki". Sen tarkasteluun sopii monille tuttu käsitepari nimby ja yimby (Not in my backyard/Yes in my backyard), jota myös Kopomaa käyttää . Näillä tarkoitetaan uusien asioiden vastustamista tai suosimista omassa lähiympäristössä. Kirjassa painottuu "yimbyily", aktiivisten ja osaavien asukkaiden toiminta esimerkiksi uuden tiedon ja kilpailevien tai täydentävien suunnitelmien tuottajina.

Kirjassa saa eniten huomiota OURCity-ohjelma. Vuonna 2011 aloitetussa hankkeessa työskenneltiin monella tavalla Vuosaaren kaupunginosassa yhdessä paikallisten asukkaiden kanssa. Projekti oli merkittävä myös sen vuoksi, että suuri osa asukkaista on taustaltaan maahanmuuttajia. Hanke järjesti mm. 
työpajoja, näyttelyitä ja teki vaihtoehtoisen kaavasuunnitelman Meri-Rastilaan tavoitteenaan yhteisöllisempi ja elävämpi ympäristö. Kaavassa pyrkimyksenä oli säästää arvostettu rantametsä täydennysrakentamiselta. Taustalla toimi yliopistotutkijoiden tukema kaupunkiaktivistien ryhmä, joka verkostoitui viranomaisten, yritysten ja eri paikallisyhteisöjen kanssa. Yhteistyötä tehtiin esimerkiksi Pro Meri-Rastila -liikkeen ja Meri-Rastilan aluefoorumin kanssa. Suunnitelmien työstäminen tapahtui pääasiassa työpajoissa. Vaihtoehtoinen kaava laadittiin vuonna 2012, jolloin Helsinki oli maailman designpääkaupunki. Kopomaa pitää mielestäni oikeutetusti kaavahankettakin yimby-suunnitelmana, sillä ehdotuksessa oli Vuosaareen luonnosteltu lähes yhtä paljon uusia asuntoja kuin silloisen kaupunkisuunnitteluviraston laajemman rakentamisen visiossa. OURCity halusi edistää asukaslähtöistä kaupunkisuunnittelua ja tarjota ideoita valmisteilla olevan asemakaavan kehittämiseen, mutta yhteiskehittelyyn asti ei päästy.

Kirjan parasta antia on leppoisa, mukaansa tempaava kirjoitustapa, joka varsinkin esimerkkitapausten esittelyssä tuo joidenkin sosiaalitieteiden klassikkojen kirjoitustavan mieleen. Kirjaa voi lukea myös laadullisen tutkimuksen menetelmäoppaana. Aihepiirin yhteiskunnallinen konteksti jää kuitenkin ohueksi. Olisin mielelläni lukenut enemmän kaupunkikehittämiseen tavalla tai toisella osallistuvista toimijoista. Osapuolia on paljon - poliittisia päättäjiä, suunnittelijoita, elinkeinoelämän ja rahoittajien edustajia, kansalaisaktivisteja. Näiden keskinäiset roolit ja voimasuhteet vaihtelevat - sekä tapauksittain että ajan myötä.

Helsingin täydennysrakentamisessa uutta suuntaa ovat näyttäneet Kampin liikekeskuksen, Keski-Pasilan ja kauppakeskus Redin toteuttaminen, missä perinteinen kunnallisdemokratia on ollut lujilla. Suunnittelutehtävät kilpailutetaan ja hankekokonaisuus etenee palasina. Hankkeissa ei voi menestyä vain sillä, että osaa rakentaa laadukkaasti. Tarvitaan myös ymmärrystä siitä, miten kohde toimii kaupallisesti ja miten se saadaan tuottavaksi yrityksille, jotka valitsevat sen liikepaikakseen. Tässä onnistuminen edellyttää, että ymmärretään myös asiakkaita ja asukkaita, missä ihmiset haluavat liikkua, asioida ja viihtyä.

Olen kirjoittajan kanssa samaa mieltä siinä, että voimme pitää kaupunkia alustana, välittäjänä tai käyttöliittymänä, joka luo edellytyksiä erilaisille toimijuuksille. Pidän myös eri vaihtoehtojen kuvauksia (täydentyvä, mukautuva, sulautuva ja eriytyvä kaupunki) osuvina. Kopomaa etenee vielä tästä arvioimalla kaupunkia täydentävän toteutuksen ympäristösidosta ja alueidentiteettiä erikseen kaikissa neljässä vaihtoehdossa ja rakentaa niiden avulla sarjan nelikenttiä sen mukaan, leimaako täydennysrakentamista näiden myönteinen tai neutraali painotus. Aloin pohdiskella ympäristön laadun ja kehityksen 
kestävyyden suhdetta Kopomaan mallinnukseen - esteettisiä ominaisuuksia, luontotyyppien uhanalaisuutta, kulttuuriympäristön harvinaisuuksia sekä ympäristön ekologista, taloudellista ja sosiaalista kestävyyttä. Mallinnus tarjoaa rakenteellisen tarkastelukehikon, mutta ei sisällöllisiä eväitä kaupunkia täydentävien hankkeiden arvioimiseksi ympäristön laadun tai toteutuspäätösten demokratian kannalta. Kirjan otsikko täydellistyvästä kaupungista jää lunastamatta.

Mielestäni kirja on onnistunut siinä, että mallinnuksen vaihtoehdot erottelevat uskottavasti kaupunkia täydentäviä rakenteita ja toiminnallisia toteutuksia. Useimpia tapauskohtaisia esittelyitä pidän erityisen kiinnostavina. Uskon, että kirja innostaa kaupunkikehittämisestä kiinnostuneita kansalaisia ja toimii kaupunkitutkimuksen opetukseen liittyvänä lukemistona. Mallin vaihtoehtojen toimivuuden testaaminen olisi kuitenkin edellyttänyt selkeämpiä laatukriteereitä, jotta niillä olisi käyttöä myös kaupunkia täydentävien hankkeiden kriittisessä arvioinnissa. 